\title{
Biomass productivity of Chlorella vulgaris cultivated in fish and dairy cattle wastewaters
}

\section{Produtividade da biomassa de Chlorella vulgaris cultivada em águas residuais de peixes e gado leiteiro}

Julia Teodoro de Souza Nicolau'; João Henrique Alves Souza2; Pedro Augusto Arroyo ; ; Elias Trevisan; Ricardo Souza Vasconcellos ${ }^{4}$; Leonir Bueno Ribeiro ${ }^{4 *}$

\section{Highlights}

Microalgal biomass productivity depends on cultivation conditions.

Farm wastewater is an interesting cultivation media for microalgae.

Chlorella vulgaris was successfully grown in fish and dairy cattle wastewaters.

The wastewaters differed in chemical and nutrient composition.

C. vulgaris biomass productivity was higher in dairy cattle wastewater.

\begin{abstract}
The biomass productivity and nutrient composition of microalgae, such as Chlorella vulgaris, depend on the cultivation process and the nutrient content of growth media. Thus, in this study aimed to investigate the biomass productivity of $C$. vulgaris cultivated in fish and dairy cattle wastewaters. Thirty wastewater samples $(2.5 \mathrm{~L})$ were collected from system of production. Microalgae were cultivated in Erlenmeyer flasks containing $10 \mathrm{~mL}$ of microalgae and $1,790 \mathrm{~mL}$ of wastewater under constant light of 5,000 lux for 16 days at $25 \pm 2.0^{\circ} \mathrm{C}$. Wastewater samples differed in composition. Biomass productivity was $47 \%$ higher $(P<0.0001)$ in dairy cattle than in fish wastewater, reaching $67.61 \mathrm{~g} \mathrm{~m}^{-3}$ day-1 (dry matter basis, DM) when compared by Student's t-test $(P<0.05)$. Cultivation media also had an effect on biomass chemical composition. The C. vulgaris grown in dairy cattle wastewater was higher in crude protein and ash contents $\left(359.6 \mathrm{~g} \mathrm{~kg}^{-1} \mathrm{DM}\right.$ and $230.4 \mathrm{~g} \mathrm{~kg}^{-1} \mathrm{DM}$, respectively), whereas microalgae grown in fish wastewater had higher nitrogen-free extract content ( $347.8 \mathrm{~g} \mathrm{~kg}^{-1} \mathrm{DM}$ ). Crude fat content did not vary greatly (mean of $313.15 \mathrm{~g} \mathrm{~kg}^{-1} \mathrm{DM}$ ). The $\mathrm{pH}\left(8.0\right.$ - 8.7) and ammonia concentration $\left(0.07\right.$ to $\left.0.4 \mathrm{mg} \mathrm{L}^{-1}\right)$ in fish wastewater was stable throughout the 16-day experimental period. In dairy wastewater, $\mathrm{pH}$ increased up (6.3 to 8.9) to the fourth day and remained constant thereafter, and ammonia concentration increased up ( 24.3 to $28.7 \mathrm{mg} \mathrm{L}^{-1}$ ) to the eighth day and

1 Zootechnist, State University of Maringá, UEM, Maringá, PR, Brazil. E-mail: juuliateodoro00@gmail.com

2 Zootechnist, Student of the Postgraduate in Animal Science, PPZ, State University of Maringá, UEM, Maringá, PR, Brazil. E-mail: souza91.joao@gmail.com

3 Profs. Drs., Department of Chemical Engineering, UEM, Maringá, PR, Brazil. E-mail paarroyo@uem.br; eliastrevisan@ yahoo.com.br

4 Profs. Drs., Department of Animal Science, UEM, Maringá, PR, Brazil. E-mail: ricardo.souza.vasconcellos@gmail.com; ribeiro.leonir.bueno@gmail.com

* Author for correspondence
\end{abstract}

Received: Mar. 03, 2020 - Approved: Dec. 14, 2020 
then it declined $\left(2.1 \mathrm{mg} \mathrm{L}^{-1}\right)$. The $C$. vulgaris was successfully grown in both wastewaters, but productivity was higher in dairy cattle wastewater.

Key words: Chemical composition. Runoff. Microalgae.

\section{Resumo}

A produtividade e a composição de nutrientes da biomassa oriunda de microalgas, como Chlorella vulgaris, dependem do processo de cultivo e do teor de nutrientes dos meios de crescimento. Assim, este estudo teve como objetivo investigar a produtividade de biomassa de $C$. vulgaris cultivada em águas residuais da criação de peixes e de gado leiteiro. Trinta amostras $(2.5 \mathrm{~L})$ foram coletadas dos sistemas de produção. As microalgas foram cultivadas em frascos de Erlenmeyer contendo $10 \mathrm{~mL}$ de microalgas e 1,790 mL de águas residuais sob luz constante de 5,000 lux por 16 dias a $25 \pm 2,0^{\circ} \mathrm{C}$. As amostras de águas residuais diferiram na composição. A produtividade de biomassa foi $47 \%$ maior $(P<0,0001)$ nas águas residuais de produção de bovinos leiteiros do que de peixes, atingindo $67,61 \mathrm{~g} \mathrm{~m}^{-3} \mathrm{dia}^{-1}$ (base de matéria seca, MS) quando comparada pelo teste $t$ de Student $(P<0,05)$. $O$ meio de cultivo também afetou a composição química da biomassa. C. vulgaris cultivado em águas residuais de gado leiteiro teve maiores teores de proteína bruta e cinzas (359,6 $\mathrm{g} \mathrm{kg}^{-1} \mathrm{MS}$ e 230,4 $\mathrm{g} \mathrm{kg}^{-1} \mathrm{MS}$, respectivamente), enquanto microalgas cultivadas em águas residuais de criação de peixes apresentaram maior teor de extrativo não nitrogenado (347,8 g kg-1 DM). $O$ teor de extrato etéreo não variou (média de 313,15 g kg-1 MS). O pH (8,0 a 8,7) e a concentração de amônia $(0,07$ a 0,40 mg $\mathrm{L}^{-1}$ ) as águas residuais dos peixes permaneceram estáveis ao longo do período experimental de 16 dias. Nas águas residuais de laticínios, o pH aumentou $(6,3$ para 8,9$)$ até o quarto dia e permaneceu constante a partir de então, e a concentração de amônia aumentou até o oitavo dia ( 24.3 to $28.7 \mathrm{mg} \mathrm{L}^{-1}$ ) e então declinou (2.1 $\left.\mathrm{mg} \mathrm{L}^{-1}\right)$. A C. vulgaris foi cultivada com sucesso em ambas as águas residuais, mas a produtividade foi maior nas águas residuais de gado leiteiro.

Palavras-chave: Composição química. Escoamento. Microalgas.

Chlorella vulgaris is an important photosynthetic microalgal species with a variety of application possibilities. It has been used for the production of biofuel biomass, fertilizer, feed, and food (Sukačová et al., 2019; Wild et al., 2019).

Research on microalgae has grown considerably in recent decades because, in addition to providing valuable products, microalgae can be used in wastewater treatment systems. Microalgal growth and nutrient accumulation are highly dependent on the cultivation process and the nutrient content of growth media (Wild et al., 2019). Industrial and agricultural wastewater show potential as nutrient-rich cultivation media and can be used in microalgae production units as a strategy to avoid the discharge of untreated wastewater into the environment (Sukačová et al., 2019).

Large volumes of wastewater are generated in animal production. In fish farms, the volume of wastewater depends on the water exchange rate. For instance, in tilapia (Oreochromis niloticus) tanks, water must be exchanged at $0.10 \mathrm{~m}^{3} \mathrm{~h}^{-1}$ (Cyrino, Bicudo, Sado, Borghesi, \& Dairiki, 2010). Dairy farm runoff is estimated at $0.045-0.060 \mathrm{~m}^{3}$ animal $^{-1}$ day $^{-1}$, but this value may vary depending on the volume of water used to clean stalls and 
equipment (Campos et al., 2002). The reuse of agricultural wastewaters in microalgae cultivation can provide economic and environmental advantages, as they are a lowcost source of nutrients and can help to reduce water consumption (Moreno-Garcia, Gariépy, Barnabé, \& Raghavan, 2019). Algae require an adequate supply of carbon, nitrogen, and phosphorus (Moreno-Garcia et al., 2019). Nutrient and $\mathrm{CO}_{2}$ levels of fish and dairy cattle wastewater differ greatly. Thus, the objective of this study was to investigate and compare the biomass productivity of $C$. vulgaris cultivated in fish farm and dairy farm wastewaters.

For this, wastewater samples were obtained from a fish farm $\left(23^{\circ} 52^{\prime} \mathrm{S}, 52^{\circ} 04^{\prime} \mathrm{W}\right.$ $550 \mathrm{~m})$ and a dairy farm $\left(23^{\circ} 36^{\prime} \mathrm{S}, 52^{\circ} 07^{\prime} \mathrm{W}, 550\right.$ $\mathrm{m})$ both located in the state of Paraná, Brazil. The sites are classified as Aw/As according to the Köppen-Geiger climate classification. Thirty wastewater samples $(2.5 \mathrm{~L})$ were collected from system of production. Fish farm wastewater consisted of drainage water from fish tanks. Dairy farm runoff contained cattle urine and feces. Firstly, samples were characterized according to the standard methods for the examination of water and wastewater of the American Public Health Association [APHA] (2005). Total solids concentration was determined after oven drying the samples at $105^{\circ} \mathrm{C}$ by American Public Health Association (APHA, 2005). Total nitrogen was determined by the Kjeldahl method (method 984.13) according to Association of Official Analytical Chemists [AOAC] (2005). Ammonia nitrogen was determined according to method 4500$\mathrm{NH}_{3}$ of the APHA (2005) using an ion-selective electrode (Orion ${ }^{\mathrm{TM}}$ ISE Filling Solutions, CAT 951202, Thermo Fisher Scientific, Waltham, USA) and a gas permeable hydrophobic membrane (Orion ${ }^{\mathrm{TM}}$ Gas-Sensing ISE membrane 951214, Thermo Fisher Scientific,
Waltham, USA). Chemical oxygen demand was measured by the colorimetric method 5220D, according to APHA (2005). Wastewater color was measured using the platinum-cobalt scale, as described method 8025 according to Hach (1996). Turbidity was measured by absorptiometry using a portable turbidimeter (DR/2100, Hach Company, Loveland, USA), as described by method 8237 according to Hach (1996). Following characterization, samples were filtered through a $7 \mu \mathrm{m}$ filter and autoclaved at $135^{\circ} \mathrm{C}$ for $30 \mathrm{~min}$.

C. vulgaris strains were obtained from the Laboratory of Heterogeneous Catalysis for Biodiesel Production (LCHBio) of the State University of Maringá, Brazil. C. vulgaris was cultivated ( $\mathrm{pH}$ 6.0), at laboratory scale and multiplied in Detmer's medium according to Watanabe (1960). For this, was used $\mathrm{Ca}\left(\mathrm{NO}_{3}\right)_{2} \cdot 4 \mathrm{H}_{2} \mathrm{O}\left(1.00 \mathrm{~g} \mathrm{~L}^{-1}\right), \mathrm{KCl}$ $\left(0.25 \mathrm{~g} \mathrm{~L}^{-1}\right), \mathrm{MgSO}_{4} \cdot 7 \mathrm{H}_{2} \mathrm{O}\left(0.55 \mathrm{~g} \mathrm{~L}^{-1}\right), \mathrm{H}_{2} \mathrm{PO}_{4}$ $\left(0.26 \mathrm{~g} \mathrm{~L}^{-1}\right), \mathrm{FeSO}_{4} \cdot 7 \mathrm{H}_{2} \mathrm{O}\left(0.02 \mathrm{~g} \mathrm{~L}^{-1}\right)$, and A5 solution1 ( $\left.\mathrm{mL} \mathrm{L}^{-1}\right)$ Composed of $2.90 \mathrm{~g}$ $\mathrm{L}^{-1} \mathrm{H}_{3} \mathrm{BO}_{3^{\prime}} 1.81 \mathrm{~g} \mathrm{~L}^{-1} \mathrm{MnCl}_{2} \cdot 4 \mathrm{H}_{2} \mathrm{O}, 0.11 \mathrm{~g} \mathrm{~L}^{-1}$ $\mathrm{ZnCl}_{2}, 0.08 \mathrm{~g} \mathrm{~L}^{-1} \mathrm{CuSO}_{4} \cdot 5 \mathrm{H}_{2} \mathrm{O}, 0.018 \mathrm{~g} \mathrm{~L}^{-1}$ $3\left(\mathrm{NH}_{3}\right)_{2} \mathrm{O} \cdot 7 \mathrm{MoO}_{3} \cdot 4 \mathrm{H}_{2} \mathrm{O}$.

For the experiment, microalgae were cultivated in $2 \mathrm{~L}$ Erlenmeyer flasks containing $10 \mathrm{~mL}$ of inoculum and $1,790 \mathrm{~mL}$ of fish wastewater $(n=15)$ or dairy cattle wastewater ( $n=15$ ). Flasks were kept under constant light of 5,000 lux (24 h photoperiod) for 16 days at $25 \pm 2.0^{\circ} \mathrm{C}$, as measured by a digital thermohygrometer (Thermo-hygrometer 7666, Incoterm, Porto Alegre, Brazil). The experiments were aerated with $2 \mathrm{~L} \mathrm{~min}^{-1}$ atmospheric air, supplied by an air compressor (Jet Master 1/3 HP, Schulz, Joinville, Brazil).

During cultivation, $\mathrm{pH}$ was monitored at 2-day intervals (Orion Star 4, Thermo Fisher Scientific, Waltham, USA), ammonia 
nitrogen was measured at 4-day intervals using an ion-selective electrode, and growth rate were measured at 4-day intervals. Biomass concentration was determined by comparing sample absorbance at $670 \mathrm{~nm}$ (UV/Vis 1203 spectrophotometer, Shimadzu do Brasil, Barueri, Brazil) to a standard curve of microalgal dry mass (Yeh \& Chang, 2012). Biomass productivity was calculated by using the following equation:

$$
P=\frac{X_{t}-X_{0}}{t-t_{0}}
$$

where $\mathrm{P}$ is the biomass productivity, expressed as $\mathrm{g} \mathrm{L}^{-1}$ day $^{-1}$ cell dry mass (CDM); $\mathrm{Xt}$ is the biomass concentration ( $\mathrm{g} \mathrm{L}^{-1} \mathrm{CDM}$ ) at time $\mathrm{t}$ (day), and $\mathrm{XO}$ is the biomass concentration ( $\mathrm{g}$ $\mathrm{L}^{-1} \mathrm{CDM}$ ) at time t0 (day).

Dry biomass (cell concentration) was obtained by flocculation with a tannin-based flocculant (Tanfloc SL, Tanac S.A., Montenegro, Brazil). Following this procedure, samples were decanted and filtered through a 20 mesh filter. Algal biomass was oven dried (MA033/1, Marconi, Piracicaba, Brazil) at $60^{\circ} \mathrm{C}$ for $24 \mathrm{~h}$, homogenized to $1 \mathrm{~mm}$, and stored at $-8^{\circ} \mathrm{C}$.

Because the volume of biomass in each Erlenmeyer flask was small, a composite sample was prepared for chemical analyses. Moisture (method 930.15), crude protein (method 984.13), crude fat (method 954.02), crude fiber (method 962.09), and ash (method
942.05) determinations were carried out according to AOAC (2005). Crude protein was determined on the basis of total nitrogen $(\% \mathrm{~N})$ using the formula $\mathrm{CP}=\mathrm{N} \times 6.25$. The generally accepted nitrogen-to-protein conversion factors for microalgae (4.78) Lourenço, Barbarino, Lavín, Lanfer Marquez and Aidar (2004) and C. vulgaris (5.14) Tibbetts et al. (2015) were also used to calculate protein concentration. Nitrogen-free extract (NFE) was calculated using the formula NFE $=100-$ (moisture + crude protein + crude fat + crude fiber + ash), as established by AOAC (2005).

Biomass productivity data were subjected to analysis of variance (ANOVA) followed by Student's t-test $(P<0.05)$ for comparison of means. Analyses were carried out using SAS version 9 (SAS Institute, North Carolina, USA). Results of the chemical composition analysis are presented as descriptive statistics.

The biomass productivity of $C$. vulgaris differed $(\mathrm{P}<0.0001)$ between wastewaters (Table 1). Dairy cattle wastewater resulted in $47 \%$ higher productivity than fish wastewater. Microalgae grown in cattle wastewater had higher crude protein (43\%) and ash (78\%) contents (Table 1), whereas cells cultivated in fish wastewater contained a higher percentage of nitrogen-free extract (29\%). Both media resulted in similar crude fat content $(313.15 \mathrm{~g}$ $\left.\mathrm{kg}^{-1} \mathrm{DM}\right)$. 
Table 1

Biomass productivity and chemical composition (dry matter basis) of Chlorella vulgaris grown in fish and dairy cattle wastewaters

\section{Variable}

Physicochemical characteristics

\begin{tabular}{|c|c|c|}
\hline Total solids, $\mathrm{mg} \mathrm{L}^{-1}$ & 97 & 11,119 \\
\hline Total nitrogen, $\mathrm{mg} \mathrm{L}^{-1}$ & 980 & 3,200 \\
\hline Ammonia nitrogen, $\mathrm{mg} \mathrm{L}^{-1}$ & 0.13 & 133.95 \\
\hline Nitrate, $\mathrm{mg} \mathrm{L}^{-1}$ & 5.34 & 15.25 \\
\hline Nitrite, $\mathrm{mg} \mathrm{L}^{-1}$ & 0.14 & 1.46 \\
\hline Total phosphorus, mg L-1 & 0.02 & 252.00 \\
\hline Chemical oxygen demand, $\mathrm{mg} \mathrm{L}^{-1}$ & 3.50 & $7,198.3$ \\
\hline Color, uC & 54 & 4,775 \\
\hline Turbidity, FAU ${ }^{3}$ & 13 & 900 \\
\hline \multicolumn{3}{|l|}{ Productivity } \\
\hline C. vulgaris $\left(\mathrm{g} \mathrm{m}^{-3}\right.$ day $^{-1}$ ) & $31.94^{b}$ & $67.61^{\mathrm{a}}$ \\
\hline C. vulgaris (g flask ${ }^{-1}$ day $^{-1}$ ) & $0.057^{b}$ & $0.122^{\mathrm{a}}$ \\
\hline \multicolumn{3}{|l|}{ Proximate nutrients } \\
\hline Crude protein, $\mathrm{g} \mathrm{kg}^{-1}(\times 6.25)$ & 156.1 & 359.6 \\
\hline Crude protein, $\mathrm{g} \mathrm{kg}^{-1}(\times 5.14)$ & 128.4 & 295.7 \\
\hline Crude protein, $\mathrm{g} \mathrm{kg}^{-1}(\times 4.78)$ & 119.4 & 275.0 \\
\hline Crude fat, $\mathrm{g} \mathrm{kg}^{-1}$ & 316.8 & 309.5 \\
\hline Ash, $\mathrm{g} \mathrm{kg}^{-1}$ & 179.4 & 230.4 \\
\hline Nitrogen-free extract, $\mathrm{g} \mathrm{kg}^{-1}$ & 347.8 & 100.5 \\
\hline
\end{tabular}

${ }^{1}$ Drainage water from fish tanks. ${ }^{2}$ Dairy farm runoff containing cattle manure and urine. ${ }^{3}$ Formazin attenuation unit. Standard error of mean to C. vulgaris $\left(\mathrm{g} \mathrm{m}^{-3}\right.$ day $\left.^{-1}\right)=2.82$ and Standard error of mean to $C$. vulgaris $\left(\mathrm{g} \mathrm{flask}^{-1}\right.$ day $\left.^{-1}\right)=$ 0.005. a,b Means in a row followed by different letters are significantly different by Student's $t$-test $(P<0.05)$.

The $\mathrm{pH}$ (Figure 1) of fish wastewater remained stable throughout the 16 days of cultivation. The $\mathrm{pH}$ of cattle wastewater increased in the first four days and remained stable thereafter. Ammonia nitrogen concentration (Figure 1) was low and stable
Fish wastewater $^{1}$ $(n=30)$

Dairy cattle wastewater ${ }^{2}$ $(n=30)$

1,119

15.25

198.3

4,775

156.

275.0

309.5

100.5 throughout the 16 days of microalgal cultivation in fish wastewater. In dairy cattle wastewater, ammonia nitrogen concentration increased up to the eighth day of cultivation and then gradually declined. 


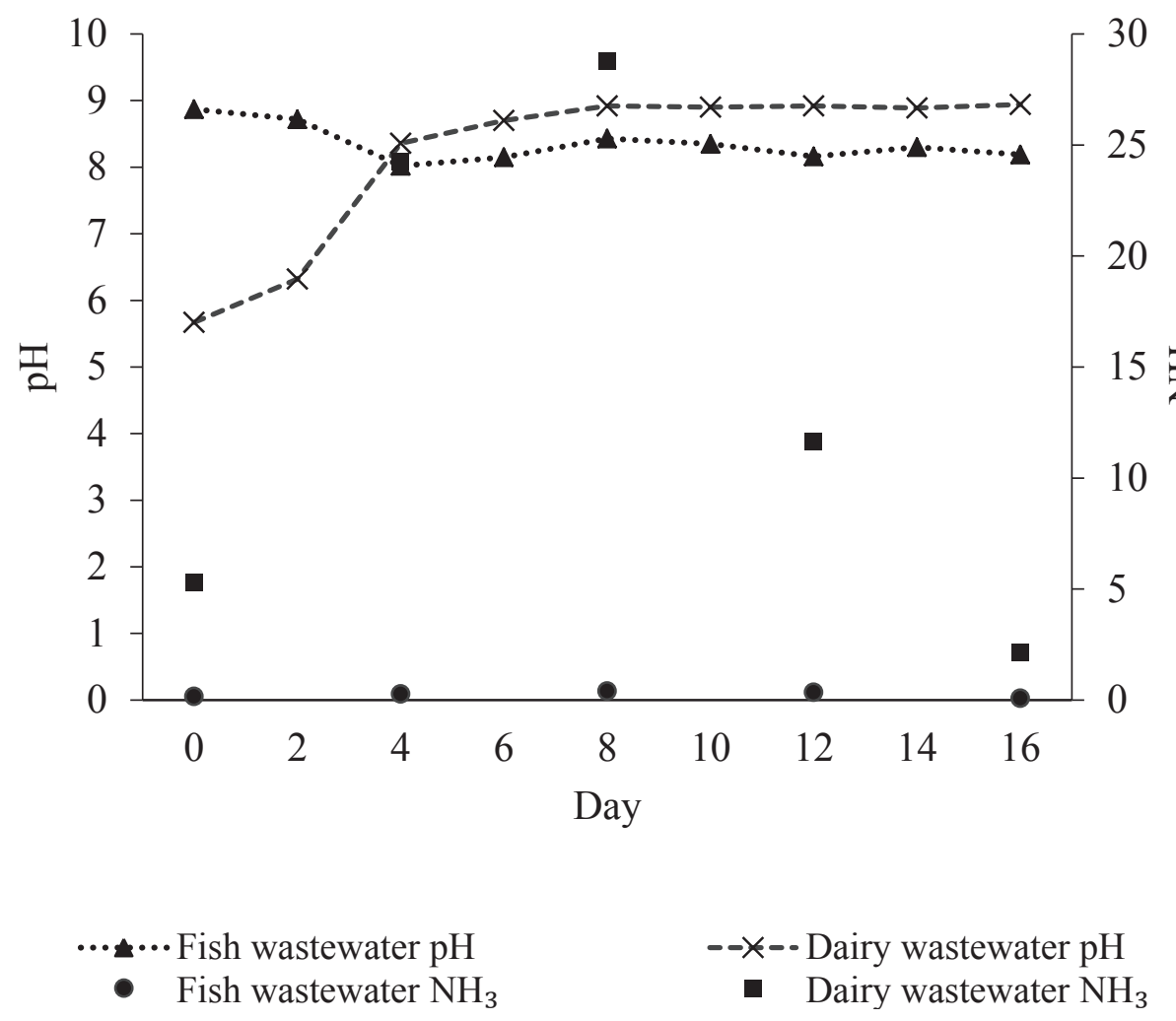

Figure 1. Ammonia nitrogen concentration $\left(\mathrm{NH}_{3^{\prime}} \mathrm{mg} \mathrm{L}^{-1}\right)$ and $\mathrm{pH}$ of fish and dairy cattle wastewaters during 16 days of Chlorella vulgaris cultivation.

In this study, we investigated the feasibility of cultivating C. vulgaris in fish and cattle wastewater. Microalgae grown in these media differed in biomass productivity and nutrient composition, which was expected, as the two wastewaters differed greatly in composition (Table 1) and microalgal production is directly influenced by the concentration of substrates in the medium (Wild et al., 2019). Previous studies reported similar findings (Moreno-Garcia et al., 2019; Wild et al., 2019).

Wild et al. (2019) and Sukačová et al. (2019) reported biomass productivities of 0.22 and $0.23 \mathrm{~g} \mathrm{~L}^{-1}$ day $^{-1}$, respectively, for Chlorella sp. cultivated in different concentrations of nutrients. In the present study, values were much lower $\left(0.032\right.$ and $0.068 \mathrm{~g} \mathrm{~L}^{-1}$ day $^{-1}$ for microalgae grown in fish and cattle wastewater, respectively). Other studies also obtained higher biomass productivities (Sukačová et al., 2019; Wild et al., 2019). Our productivity values were close to those obtained by Wild et al. (2019) under $\mathrm{CO}_{2}$-deficient conditions and by Moreno-Garcia et al. (2019) in a blend of wastewaters. It is likely that the cause of such low productivity was the lack of essential nutrients, such as nitrogen and $\mathrm{CO}_{2}$ (MorenoGarcia et al., 2019; Wild et al., 2019). Gouveia et al. (2016), studying the treatment of urban wastewater with $\mathrm{C}$. vulgaris, obtained mean biomass productivity of $0.05 \mathrm{~g} \mathrm{~L}^{-1}$ day $^{-1}$.

The proximate nutrient composition of $C$. vulgaris biomass was in agreement with 
values previously reported in the literature for the species (Gouveia et al., 2016; Wild et al., 2019). Halfhide, Åkerstrøm, Lekang, Gislerød and Ergas (2014), studying aquaculture wastewater treatment, noted that microalgae should be harvested at the peak production of the desired product. The authors observed mean biomass productivity of $4.89 \mathrm{mg} \mathrm{L}^{-1} \mathrm{~h}^{-1}$ for $C$. vulgaris and expressive nitrogen removal (18\%).

Microalgal growth and biomass productivity can be influenced by several factors, including light (quality and quantity), temperature, $\mathrm{pH}$, salinity, qualitative and quantitative nutrient profiles, dissolved oxygen concentration, and presence of toxic compounds in the medium (Gonçalves, Pires, \& Simões, 2017). The optimum $\mathrm{pH}$ range for most microalgal species is between 7.0 and 9.0 (Gonçalves et al., 2017). Because pH changes can negatively impact microalgal metabolism, it is crucial to maintain the growth medium at a stable $\mathrm{pH}$ within the optimum range to avoid culture loss (Gonçalves et al., 2017). Fish wastewater $\mathrm{pH}$ and ammonia nitrogen concentration (Figure 1) were stable over the days. Wastewater from dairy cattle showed a marked increase in $\mathrm{pH}$ until the fourth day and ammonia nitrogen concentration until the eighth day of cultivation, followed by a gradual reduction (Figure 1).

In microalgal production, it is common to observe an increase in $\mathrm{pH}$ resulting from $\mathrm{CO}_{2}$ uptake (Halfhide et al., 2014; Gonçalves et al., 2017), but this may have limited microalgal growth and productivity. Moreno-Garcia et al. (2019) concluded that the exponential growth phase of microalgae lasted until the sixth day of cultivation when increasing concentrations of organic carbon and $\mathrm{CO}_{2}$ led to reduced growth.
Increased ammonia nitrogen may be associated with the leaching processes of organic (protein, sugars, organic acids) and inorganic ( $\mathrm{K}, \mathrm{Ca}, \mathrm{Mg}$, and $\mathrm{Mn}$ ) compounds ( $\mathrm{Li}$ et al., 2016). These compounds come from animal feed and may not have been fully leached, as this process can last from a few days to weeks. While the fall of ammonia nitrogen is related to the consumption and depletion of compounds that are nitrogen sources for the formation of microalgae. Nitrogen deprivation is the most widely used strategy to redirect protein synthesis to lipid synthesis and enhance the biomass value of microalgae for biodiesel production. According to $\mathrm{Li}$ et al. (2016), nitrogen is the most critical single nutrient affecting lipid accumulation in microalgae. The most common forms of inorganic nitrogen are $\mathrm{NO}_{3}-\mathrm{N}, \mathrm{NH}_{4}-\mathrm{N}$, and urea (Halfhide et al., 2014; Gonçalves et al., 2017).

In this study, the effects of nitrogen deprivation on nutrient accumulation were clear. Microalgae grown in dairy cattle wastewater had higher crude protein content than those cultivated in fish wastewater (Halfhide et al., 2014; Wild et al., 2019). Li et al. (2016) noted that it is essential to maintain a balance between low nitrogen stress and high photosynthetic capacity by regulating the initial nitrogen supply to maximize lipid yield.

Phosphorus is required in the form of soluble phosphates and should be supplied in large quantities because not all phosphorus compounds are bioavailable for microalgae (Halfhide etal., 2014; Gonçalves etal., 2017). The higher proportion of nitrogen and phosphorus in dairy cattle wastewater resulted in higher protein synthesis (Table 1). These findings are consistent with the literature (Wild et al., 2019). In general, microalgae have high nitrogen and phosphorus removal efficiencies, ranging from 
60-99 \% and 54-95\%, respectively (Gonçalves et al., 2017).

Fish and dairy cattle wastewaters proved to be suitable media for $C$. vulgaris cultivation, but cattle wastewater led to higher biomass productivity. The results indicate that it is technically feasible to cultivate microalgae in dairy cattle wastewater. This environmentally friendly technique obviates the need for freshwater and expensive substrates. Future studies should evaluate the existence of possible contaminants such, as undesirable microorganisms.

\section{References}

American Public Health Association (2005). American water works association and water environment federation. Standard methods for the examination of water and wastewater (21nd). Washington DC, USA.

Association of Official Analytical Chemists (2005). Official methods of analysis of AOAC international (18nd ed.). Gaithersburg, Maryland, USA. AOAC International.

Campos, A. T., Ferreira, W. A., Paccola, A. A., Lucas, J. Jr., Cardoso, R. M., \& Campos, A. T. (2002). Aerobic biological treatment and recycling of bovine manure in intensive system of milk production. Ciência e Agrotecnologia, 26(2), 426-438.

Cyrino, J. E. P., Bicudo, A. J. A., Sado, R. Y., Borghesi, R., \& Dairiki, J. K. (2010). Fish farming and the environment-the use of environmental friendly feeds in fish culture. Revista Brasileira de Zootecnia, 39(Suppl.), 68-87. doi: 10.1590/S1516-35 982010001300009
Gonçalves, A. L., Pires, J. C., \& Simões, M. (2017). A review on the use of microalgal consortia for wastewater treatment. Algal Research, 24(part B), 403-415. doi: 10.1016/j.algal.2016.11.008

Gouveia, L., Graça, S., Sousa, C., Ambrosano, L., Ribeiro, B., Botrel, E. P.,... Silva, C. M. (2016). Microalgae biomass production using wastewater: treatment and costs: scaleup considerations. Algal Research, 16, 167-176. doi: 10.1016/j.algal.2016.03.010

Hach, D. R. (1996). Spectrophotometer procedures manual. Loveland, CO, USA: $\mathrm{HACH}$ Company.

Halfhide, T., Åkerstrøm, A., Lekang, O. I., Gislerød, H. R., \& Ergas, S. J. (2014). Production of algal biomass, chlorophyll, starch and lipids using aquaculture wastewater under axenic and non-axenic conditions. Algal Research, 6 (part B), 152159. doi: 10.1016/j.algal.2014.10.009

Li, T., Xu, J., Gao, B., Xiang, W., Li, A., \& Zhang, C. (2016). Morphology, growth, biochemical composition and photosynthetic performance of Chlorella vulgaris (Trebouxiophyceae) under low and high nitrogen supplies. Algal Research, 16(1), 481-491. doi: 10.1016/j.algal.2016.04.008

Lourenço, S. O., Barbarino, E., Lavín, P. L., Lanfer Marquez, U. M., \& Aidar, E. (2004). Distribution of intracellular nitrogen in marine microalgae: calculation of new nitrogen-to-protein conversion factors. European Journal of Phycology, 39(1), 1732. doi: 10.1080/0967026032000157156

Moreno-Garcia, L., Gariépy, Y., Barnabé, S., \& Raghavan, G. S. V. (2019). Effect of environmental factors on the biomass and lipid production of microalgae grown 
in wastewaters. Algal Research, 41(1), 101521. doi: 10.1016/j.algal.2019.101521

Sukačová, K., Búzová, D., Trávníček, P., Červený, J., Vítězová, M., \& Vítěz, T. (2019). Optimization of microalgal growth and cultivation parameters for increasing bioenergy potential: Case study using the oleaginous microalga Chlorella pyrenoidosa Chick (IPPAS C2). Algal Research, 4O(1), 101519. doi: 10. 1016/j. algal.2019.101519

Tibbetts, S. M., Whitney, C. G., MacPherson, M. J., Bhatti, S., Banskota, A. H., Stefanova, R., \& McGinn, P. J. (2015). Biochemical characterization of microalgal biomass fromfreshwaterspeciesisolated in Alberta, Canada for animal feed applications. Algal Research, 11(1), 435-447. doi: 10.1016/j. algal. 2014.11.011
Watanabe, A. (1960). List of algal strains in collection at the Institute of Applied Microbiology, University of Tokyo. The Journal of General and Applied Microbiology, 6(4), 283-292. doi: https:// doi.org/10. 2323/jgam.6.283

Wild, K. J., Trautmann, A., Katzenmeyer, M., Steingaß, H., Posten, C., \& Rodehutscord, M. (2019). Chemical composition and nutritional characteristics for ruminants of the microalgae Chlorella vulgaris obtained using different cultivation conditions. Algal Research, 38(1), 101385. doi: 10.1016/j. algal. 2018.101385

Yeh, K. L., \& Chang, J. S. (2012). Effects of cultivation conditions and media composition on cell growth and lipid productivity of indigenous microalga Chlorella vulgaris ESP-31. Bioresource Technology, 105(1), 120-127. doi:10.1016/ j.biortech.2011.11.103 
